\title{
Unfair Competition in Ideas and Titles
}

\section{Rudolf Callmann*}

TDEAS ARE weapons, they are the soil on which we grow, they are the life1 blood of competition, and the theft of ideas is the lifeblood of unfair competition. Many a new industry and many a fortune has been built upon a properly exploited idea. But what protection does the law give to the idea itself? Unfortunately, very little.

Take, for example, the enterprising life insurance salesman with a rural territory. ${ }^{1}$ He could never get his farmer prospects to give him enough time to expound upon the virtues of his company's policy. The farmer would always excuse himself because it was either milling, weeding or plowing time. The agent got a brainstorm. He took an all-around hired man with him and whenever a farmer tried to excuse himself, the agent would send the hired man to do the farmer's chores. With his new-found leisure, the farmer had no alternative and the agent then launched into his sales talk. The idea was a success. Now suppose another agent tried to do the same thing. Could our enterprising salesman prevent him from capitalizing on that approach? The answer is no. Take another example. The late Clarence Saunders, the founder of the Piggly Wiggly Stores, conceived a new selfservice supermarket. Could he stop a competitor from establishing a store at which customers serve themselves and pay on the way out? Again the answer is no.

And the same answer was given by the courts to someone who conceived a new radio program, planning the format, suggesting length of the program, the type of participants and other elaborately worked out details. ${ }^{2}$ A similar fate awaited the fellow who hit upon a new method of teaching bridge ${ }^{3}$ or a new advertising idea, even though einbodied in a script ${ }^{4}$ or a ship-to-shore communication service for travelers; ${ }^{5}$ or a fully-developed plan for a miniature railroad exhibit at the New York World's Fair. ${ }^{6}$

Sailors often say "Any port in a storm." But is there any legal port for the brainstorm? Why do our courts look with such disfavor upon ideas?

* Member, New York Bar.

1 Reader's Digest, Sept. 1938, p. 114.

2 Bowen v. Yankee Network, Inc., 46 F. Supp. 62 (D. Mass. 1942); Belt v. Hamilton National Bank, 108 F. Supp. 689 (D.D.C. 1952).

3 Downes v. Culbertson, 153 Misc. 14, 275 N.Y. Supp. 233 (Sup. Ct. 1934).

4 Stone v. Liggett \& Myers Tobacco Co., 260 App. Div. 450, 23 N.Y.S.2d 210 (1st Dep't 1940); Alberts v. Remington Rand Inc., 175 Misc. 486, 23 N.Y.S.2d 892 (Sup. Ct. 1940). 1940).

5 Rodriguez v. Western Union Tel. Co., 259 App. Div. 224, 18 N.Y.S.2d 759 (1st Dep't 1939).

${ }^{6}$ Williamson v. New York Central R.R., 258 App. Div. 226, 16 N.Y.S.2d 217 (2d Dep't 
The courts rationalize their unwillingness to protect the idea itself by resorting to the rule that there is no property right in a mere abstract idea, even if the idea is new and original. They say that it would be too difficult to enforce such a right, and they have almost uniformly refused to recognize any property right in an idea unless it has either been reduced to a concrete forn or it exists in a distinctly unusual arrangement and combination of ideas-in the form, sequence and manner in which the composition expresses the idea. It seems, however, that this approach is more a statement of result than a basic legal principle. Only when the courts can find a concrete manifestation of the idea, even though it may lack absolute novelty, ${ }^{7}$ will they consider the legal theory on which they could give the plaintiff relief. If the courts are hesitant to grant protection they normally excuse their reluctance by saying that the plaintiff was "under no obligation to disclose his plan."8 Or they might say, if the plaintiff failed to safeguard

${ }^{7}$ Kurlan v. Columbia Broadcasting System, 40 Cal.2d 799, 256 P.2d 962 (1953).

8 Moore v. Ford Motor Co., 28 F.2d 529 (S.D.N.Y. 1928), aff'd, 43 F.2d 685 (2d Cir. 1930) (syllabus). Plaintiff offered to submit a salesplan to defendant which the latter accepted and encouraged, with the result that plaintiff provided defendant with the plan.

In Sachs v. Cluett, Peabody \& Co., 265 App. Div. 497, 500, 39 N.Y.S.2d 853, 856 (1st Dep't 1943), the court said: "The plaintiff maintains that he does not plead and need not rely upon his contract but that he pleads upon a violation of a confidential relationship. Broadly speaking, confidential relationship is synonymous with fiduciary relationship and the equity text writers classify it under that heading. It exists between trustee and cestui que trust, guardian and ward, attorney and client, principal and agent or employer and employee and generally where the parties do not deal on equal terms and one trusts and relies on the other. Parties dealing at arm's length, each seeking for himself the best advantage to be derived from a transaction, are not in confidential relationslip. The recitals of the complaint indicate that prior to disclosure by plaintiff of his secret there were negotiations between the parties leading to the agreement rclied upon and the rights and obligations of the parties are based on their contract."

In Folsom v. Great A.\& P. Tea Co., 268 App. Div. 912, 51 N.Y.S.2d 744 (2d Dep't 1944), affd, 294 N.Y. 934, 63 N.E.2d 121 (1945), an express agreement existed, and plaintiff was successful.

In Whitunan v. Metro-Goldwyn-Mayer Corp., 159 Misc. 850, 289 N.Y. Supp. 961 (Sup. Ct. 1936), plaintiff endeavored to interest defendants in distributing his one-reel moving picture "Inflation." He exhibited it to the defendants, but they rejected it as unsuitable for their use. Shortly afterward, defendants produced a one-reel moving picture entitled "Inflation." The court found, however, that there was no unfair imitation.

In Anderson v. Distler, 173 Misc. 261, 17 N.Y.S.2d 674, (Sup. Ct. 1940), an insurance agent, who lad given defendant a valuable suggestion in respect to the retention of insurance, failed in seeking damages for the disclosure of his idea, for lack of a contract.

The doubt raised in this case, as to whether an idea can be the subject matter of a contract, was removed in Alberts v. Remington Rand, 175 Misc. 486, 487, 23 N.Y.S.2d 892, 894 (Sup.Ct.1940), where the court stated the present rule, as follows: "In the absence of an express agreement the originator or proprietor of an idea, trade, secret or system which cannot be sold, negotiated or used without disclosure, cannot liold another liable, if he uses the idea for his own benefit .... Only where the idea has been reduced to concrete forn prior to its disclosure to and appropriation by the defendant may recovery be had upon an implied contract."

Plus Promotions v. RCA Mfg. Co., 49 F. Supp. 116 (S.D.N.Y.1943) requires in addition that the novel idea be divulged in concrete forn under circumstances indicating that compen. sation is expected if the idea is used (discussing cases). 
his idea by a proper contractual agreement, that he "invited his own disaster." Only if the courts are ready to grant protection do they query whether the plaintiff could sue upon express contract, ${ }^{10}$ or on the breach of an implied obligation, ${ }^{11}$ sometimes tied to the tail of trade, custom or usage, ${ }^{12}$ or upon quantum meruit, this much too neglected cause of action.

The \$64 question, however, is still with us. How can we anticipate when a court will be satisfied that the idea or the combination of ideas is expressed in a sufficiently concrete form? As lawyers we must face up to the problems that our clients will present and if we are to help them we inust be able to make an intelligent prediction as to a court's reaction. Is the client's idea so original and is his development of it sufficiently umique to

9 Mitchell Metal Products v. Berkeley Equipment Co., 36 F. Supp. 1010 (W.D. Pa. 1941) discussed the question of consideration in a contract to maintain the secrecy of a confided idea, and held that such a contract is not unilateral; the order by plaintiff was given as consideration for the pledge of secrecy, Shubert v. Columbia Pictures Corp., 189 Misc. 734, 72 N.Y.S.2d 851 (Sup. Ct. 1947). In Folsom v. Great A. \& P. Tea Co., 268 App. Div. 912, 51 N.Y.S.2d 744 (2d Dep't 1944), aff'd, 294 N.Y. 934, 63 N.E.2d 121 (1945) and in Ellis Displays, Inc. v. Magicarve Gems, Inc., 77 U.S.P.Q. 432 (N.Y. Sup. Ct. 1948), plaintiffs were careful to protect themselves by express contract. In Boucher v. Wissman, 206 S.W.2d 101 (Tex. Civ. App. 1947), the court pointed out that it was not alleged that defendant had agreed to keep secret any knowledge he acquired from the plaintiff; nor were there any facts from which such an obligation could be inferred.

In Pennington Engineering v. Spicer Mfg. Corp., 165 F.2d 59 (6th Cir. 1947), the information was conveyed to many manufacturers, under no promise of secrecy, in order to interest them in a certain device.

10 Compare Masline v. New York, N.H. \& H.R. Co., 95 Conn. 702, 112 Atl. 639 (1921); Soule v. Bon Ami Co., 201 App. Div. 794, 195 N.Y. Supp. 574 (2d Dep't 1922), af'd, 235 N.Y. 609, 139 N.E. 754 (1923), where courts demed relief, with Elfenbein v. Luckenbach Terminals, 111 N.J.L. 67, 166 Atl. 91 (1933) ; High v. Trade Union Courier Pub. Corp., 69 N.Y.S.2d 526 (Sup. Ct. 1946), aff'd, 275 App. Div. 803, 89 N.Y.S.2d 527 (1st Dep't 1949) and Larx Co. v. Nicol, 224 Minn. 1, 28 N.W.2d 705 (1946), where express contracts were enforced.

11 Liggett \& Myers Tobacco Co. v. Meyer, 101 Ind. App. 420, 194 N.E. 206 (1935). The decision has been criticized as extending too far, Note, 44 YALE L.J. 1269, 1270 (1935), and as representing a salutary extension of the ever-expanding concept of property. Note, 21 CoRN. I.Q. 486 (1936) ; Booth v. Stutz Motor Car Co. of America, 56 F.2d 962 (7th Cir. 1932) (improvement for motor cars); Stanley v. Columbia Broadcasting System, 192 P.2d 495 (1948), affd, 35 Cal.2d 653, 221 P,2d 73 (1950) (radio program and script); Golding v. R.K.O. Radio Pictures, 35 Cal.2d 690, 221 P.2d 95 (1950) (stage play).

Ryan \& Associates v. Century Brewing Ass'n, 185 Wash. 600, 55 P.2d 1053 (1936), as to the advertising slogan "The Beer of the Century."

See also Healey v. R. H. Macy \& Co., 251 App. Div. 440, 297 N.Y. Supp. 165 (1st Dep't 1937), as to the slogan "A Macy Christmas and Happy New Year." The theory of unjust enrichment was rejected in Grombach Productions, Inc. v. Waring, 293 N.Y. 609, 616, 59 N.E.2d 425, 428 (1944).

Pressed Steel Car Co. v. Standard Steel Car Co., 210 Pa. 464, 60 Atl. 4 (1904). Ketcham v. New York World's Fair 1939, 34 F. Supp. 657 (E.D.N.Y. 1940), aff'd, 119 F.2d 422 (2d Cir. 1941). In Nash v. Alaska Airlines, Inc., 88 U.S.P.Q. 85 there was a clear contract.

12 Compare Grombach Productions, Inc. v. Waring, 293 N.Y. 609, 59 N.E.2d 425 (1944) with Kovacs v. Mutual Broadcasting System, 99 Cal. App.2d 56, 221 P.2d 108 (1950) and Kurlan v. Columbia Broadcasting System, 40 Cal.2d 799, 256 P.2d 962 (1953). 
give him a legally protectible interest? Has he put enough flesh on the skeleton of his idea to give it body? To put it differently, has the client come up with something more substantial than a variation on a generalized theme? Has he given it a special treatment or added a new method of performance, or reduced it to a concrete form? Has he so developed the characters, plot and personalities to make them clearly recognizable?

In shaping our counsel, we must appreciate the reasons why courts are reluctant to crawl out on the proverbial limb and insist upon the expression of the idea in a concrete form. First, there is the administrative difficulty. As one court said, "when ideas are expressed in some concrete form, the proof may be certain and administrative difficulties are not so great." ${ }^{13}$ Then, too, the court will cast a suspicious eye on an idea unless its concrete form makes it quite evident that it can be appropriated by someone else. To quote from one of the most fundamental decisions in the law of unfair competition, the Supreme Court opinion in International Neres Service v. Associated Press, ${ }^{14}$ the court will search to find that the defendant has taken "material that has been acquired by complainant as the result of organization and the expenditure of labor, skill and noney and which is salable by complainant for money." Borrowing language from the patent law: the idea must be expressed in such a manner that its concrete manifestation enables anyone to reduce it to practice without further effort.

Then, too, a further difficulty arises out of the threatening abundance of bright ideas that seek protection and in the peculiar relationship of offeror and offeree. Big business is constantly besieged by enterprising young men anxious to sell revolutionary new ideas equivalent to the famous advice once given to Coca-Cola in the words "Bottle it." Whether it be a merchandising gimmick, a product or an advertising idea, the originator always insists that his contribution is deserving of a monetary reward. He believes his idea is novel, and the offeree fears that the idea might turn out to be old hat; both parties want agreements which are mutually exclusive, the idea man looking for secrecy and compensation, while the offeree is insisting upon disclosure, freedom to investigate the idea and to fix an even-

13 Acy v. Whaley, 281 Ky. 400, 406, 136 S.W.2d 575, 579 (1940). Here the court said: "Though the defendant did plagiarize plaintiff's idea and did copy the general form of his production so as to give it the general appearance of being the same, and, therefore, from a strictly ethical standpoint treated the plaintiff unfairly, still the nature of the act does not make it unfair competition withm the law. It is damnum absque injuria." (italics added). This raises the suspicion that the case was not rightly decided; the court unfortunately failed to distinguish between functional and nonfunctional elements.

14248 U.S. 215, 239 (1918), affirming, 245 Fed. 244 (2d Cir. 1917), which modified 240 Fed. 983 (S.D.N.Y. 1917), discussed in Notes, 4 CoRN. L.Q. 223 (1919) ; 13 ILL. L. REv. 708 (1919); 2 Minv. L. Rev. 305 (1918); 32 HaRv. L. Rev. 566 (1919); 17 MicH. L Rev. 490 (1919); 67 U. of PA. L. REv. 191 (1919); 28 YaLe L.J. 387 (1919). For a comment on the case in the lower court, see 18 Cor. L. REv. 257 (1918). 
tual compensation. Too often the fear of legal complications might lead big business to discourage the revelation of ideas. We are involved not only with the contractual relationship between offeror and offeree but also with the competitive relationship between the offeree and his rivals. If, for example, we find that the offeree is obligated to pay compensation for the revelation, the presumption is justified that he is entitled to protection of the idea against a competitor's misappropriation.

These principles allow sufficient room for judicial preference. As in all human decisions, so here, too, the emotions may control. Applying these principles, we find that the California courts have shown greater liberalism in this field than the courts of the East. This Califormian liberalism is especially evident in the law of unfair competition and trade-mark mfrimgement, where the doctrine of dilution has been accepted. ${ }^{15}$

It is true, however, that recently the California Supreme Court, in the Weitzenkorn, Kurlan and Burtis cases, so narrowly construed the 1947 amendment to section 980 of the California Civil Code as to deprive the idea of any protection in holding that only the "representation or expression of a composition"16 will be protected.

Let's go back to our examples. Is the scheme of our enterprising insurance agent or is Mr. Saunders' approach to the supermarket too abstract to be a sufficiently concrete manifestation? The courts say yes, but, quite frankly, I don't understand why.

Some courts have found the required concrete manifestation of an underlying idea and have granted it protection. Material suitable for radio broadcasts and motion pictures, ${ }^{17}$ for a program of a show with changing drama and comment, ${ }^{18}$ and the scenario and synopsis for a photoplay, ${ }^{19}$ have all been protected. Even phrases, pictures or slogans to be used in advertising layouts like "The Beer of the Century," 20 or "A Macy Christmas and Happy New Year" ${ }^{21}$ were protected. A detailed plan for the manufacture, design, packaging and labelling of candy tablets, ${ }^{22}$ a plan involving the form and substance of newspaper interviews ${ }^{23}$ and an underlying idea

\footnotetext{
16 Stork Restaurant Inc. v. Sahati, 166 F.2d 348 (9th Cir. 1948).

10 Weitzenkorn v. Lesser, 40 Cal.2d 778, 256 P.2d 947 (1953); Kurlan v. Columbia Broadcasting System, 40 Cal.2d 799, 256 P.2d 962 (1953); Burtis v. Universal Pictures Company, 40 Cal.2d 823, 256 P.2d 933 (1953).

17 Yadkoe v. Fields, 66 Cal. App. 2d 150, 151 P.2d 906 (1944).

18 Stanley v. Columbia Broadcasting System, 35 Cal.2d 653, 221 P.2d 73 (1950).

19 Thompson v. Famous Players-Lasky Corp., 3 F.2d 707 (N.D. Ga. 1925).

20Ryan \& Associates v. Century Brewing Co., 185 Wash. 600, 55 P.2d 1053 (1936).

27. Healey v. R.H. Macy \& Co., 277 N.Y. 681, 14 N.E.2d 388 (1938), afirming, 251 App. Div. 440, 297 N.Y. Supp. 165 (1st Dep't 1937). 1941).

${ }^{22}$ American Mint Corp. v. Ex-Lax Inc., 263 App. Div. 89, 31 N.Y.S.2d 708 (1st Dep’t
}

${ }^{23}$ Jenkins v. News Syndicate Co., 128 Misc. 284, 219 N.Y. Supp. 196 (Sup. Ct. 1926). 
which eventually blossomed into a basic radio program ${ }^{24}$ were afforded judicial protection. Indeed, and this will interest every lawyer, a court even protected the disclosure of an available tax exemption. ${ }^{25}$

Let's examine the idea that was protected in an interesting California case. The idea revolved about the format of a radio program with changing drama and comment. The abstract idea was stated by the court as follows: ${ }^{20}$

An announcer and a master of ceremonies; performance of a drama; listen. ers invited to say whether they would like to see the drama in a motion picture; prizes for best letters; drama criticised by a board of judges or critics ... . But ... Plaintiff did not propose to defendant merely a plan or an outline of an idea.... He composed and wrote the words of the entire show save only each week's drama and the spontaneous comments which the critics would make. He left nothing to be inserted, nothing to be altered.

The idea for this program was protected and in another California case the format of the program "Your Heart's Desire"26a was also protected.

A Federal District Court in Massachusetts ${ }^{27}$ was not as solicitous of a rather similar idea and denied protection even though the plaintiff elaborately worked out the development for a radio program.

The plans involved in these three cases are spelled out in the opinions. Quite frankly, a comparison of the basic ideas reveals no great difference between them. They were in fact substantially similar. Yet the California courts protected the ideas, while the Massachusetts court did not.

Sometimes the very simplicity of the idea and its so-called concrete manifestation appeals so strongly to the court that it protects an idea expressed in a few words. An Indiana court, ${ }^{28}$ for example, was sufficiently intrigued to give protection to the advertising idea of a person offering a pack of sigarettes, to someone who simply answers: "No thanks, I smoke Chesterfields."

The shortest and most appealing concrete expression of an idea is of course a title-either of a book, a magazine, a play, a show or a motion picture. And there are few fields that are more inviting to the imitator. With the success of the movie "It Happened One Night," things suddenly began to happen everywhere. In quick succession, appeared such titles as "It Happened on Ice," "It Happened on 42nd Street," and so on. The success of the French movie, "The Baker's Wife" inevitably suggested, "The Baker's Daughter," and other blood relatives.

A title partakes of both a name and a trade-mark, and yet it materially differs from both. It performs the same function as an individual's name

${ }^{24}$ Cole v. Phillips H. Lord, Inc., 262 App. Div. 116, 28 N.Y.S.2d 404 (1st Dep't 1941).

${ }^{25}$ High v. Trade Union Courier Pub. Corp., 69 N.Y.S.2d 526 (Sup.Ct. 1946), aff'd, 275 App. Div. 803, 89 N.Y.S.2d 527 (1st Dep't 1949).

${ }^{26}$ Stanley v. Columbia Broadcasting Systen, 192 P.2d 495, 503, aff'd, 35 Cal.2d 653, 221 P.2d 73 (1950) (italics added).

26a Kovacs v. Mutual Broadcasting Systen, 99 Cal. App.2d 56, 221 P.2d 108 (1950).

27 Cases cited note 2 sucpra.

28 Liggett \& Myers Tobacco Co. v. Meyer, 101 Ind. App. 420, 194 N.E. 206 (1935). 
in identifying the work and it is like a trade-mark in the sense that it advertises the work, identifies its source and "guarantees the validity of copies." The title is like a trade-mark recognized as an intangible and incorporeal property right. And since a title is not subject to copyright, it is essential that it be protected as a trade-mark. It is well-settled that, like a trademark, a title is deserving of protection against the use of a confusingly similar title, if it is (1) freely chosen and (2) distinctive, or putting it otherwise, if the title is not descriptive or has acquired a distinctive secondary significance.

Similarly, a secondary meaning will only attach to a descriptive title after a not inconsiderable period of time. There are, however, some exceptions where a secondary meaning develops almost overmight. Thus, in the New York case of Manners v. Triangle Film Corporation, the District Court held that one performance by one of the foremost actresses of her time had almost contemporaneously given the title of the work a secondary siguificance. ${ }^{29}$ Certain titles are, of course, so descriptive that they can never acquire a secondary meaning. Titles, such as "A Treatise on the Law of Unfair Competition," "The Life of Napoleon," "History of the Civil War," could claim no secondary meaning except such as would be attributable not to the popularity of the title but to the fame of the work or its author. On the basis of a recoguized secondary neaning, protection has been accorded such titles as "Chatterbox," "30 "Social Register,"31 "Oxford Bible,"32 "Comfort," "Photoplay Magazine," 34 and because they were considered fanciful and distinctive, protection was granted to "Blind Youth," "The Office Economist," "Ecstasy,"37 "The House of Thousand Candles," "A Fool There Was," 39 "Queen of the Flat Tops." 40

29 Manners v. Triangle Film Corp., 244 Fed. 293 (S.D.N.Y. 1917).

30 Estes v. Williams, 21 Fed. 189 (S.D.N.Y. 1884) ; Estes v. Worthington, 31 Fed. 154 (C.C.S.D.N.Y. 1887), appeal dismissed, 145 U.S. 662 (1892).

31 Social Register Ass'n v. Murphy, 128 Fed. 116 (D.R.I. 1904).

32 The Chancellor, etc., of Oxford University v. Wilmore-Andrews Pub. Co., 101 Fed. 443 (C.C.S.D.N.Y.1900).

33 Gannett v. Ruppert, 127 Fed. 962 (2d Cir. 1904), reversing, 119 Fed. 221 (C.C.S.D.N.Y. 1902) (a monthly family magazine).

34 Photoplay Pub. Co. v. La Verne Pub. Co., 269 Fed. 730 (3d Cir. 1921), reversing, 261 Fed. 428 (E.D. Pa. 1919).

35 National Picture Theatres v. Foundation Film Corp., 226 Fed. 208 (2d Cir. 1920).

36 Art Metal Const. Co. v. Textile Pub. Co., 54 App. D.C. 75, 294 Fed. 1006 (D.C. Cir. 1924) (protected against "Dry Goods Economist").

37 Eureka Productions v. Intimate Theatres, 248 App. Div. 692, 288 N.Y.Supp. 1116 (1st Dep't 1936).

38 Selig Polyscope Co. v. Mutual Film Corp., 169 N.Y. Supp. 369 (Sup. Ct. 1918), affd, 183 App. Div. 882, 169 N.Y. Supp. 1113 (1st Dep't 1918) (protected against "The House of Thousand Scandals").

39 Klaw v. General Film Co., 154 N.Y. Supp. 988 (Sup. Ct. 1915), affd, 171 App. Div. 942, 156 N.Y. Supp. 1128 (1st Dep't 1915).

40 Johnston v. Twentieth Century-Fox Film Corp., 82 Cal. App. 2d 796, 187 P.2d 474 (1947). 
The importance of the trade-mark aspect of the title is illustrated by the New York case involving the title of the plaintiff's play, "Charley's Aunt." 11 The defendant decided to climb the same family tree and produced a play called "Charley's Uncle." The court refused an injunction: ${ }^{42}$

It cannot be urged that the plaintiff, even if he had copyrighted the title "Charley's Aunt," could have extended his right to literary protection to all the relatives of Charley's family; for it must have been known to the plaintiff that this Charley, like every other mdividual was apt not only to have aunts, but uncles, brothers, sisters, cousins, and perhaps a mother-inlaw and a grandfather. Nor would it be seriously contended that by adopting "Charley's Aunt" as the title to his play, he monopolized the right to all the other relatives.

The court completely missed the trade-mark significance of the title and the element of unfair competition.

A trade-mark is violated not only because an identical or similar mark is used for the same article but also where it is used for a different type article, and for the same reason the title of a production should be protected against an identical or similar title for a quite different production. In the New York case of Frohman v. Morris, ${ }^{43}$ the court had before it two performances of a completely different nature, one being serious and artistic, the other a burlesque. Though, as the court said, no one intending to witness the plaintiff's play could possibly mistake the defendants' performance for it,

... this power to distinguish [between the two] would not save the playgoer who had gotten into the wrong theater. His money would have been paid and his evening would have been irretrievably lost. It is manifest, also, that confusion and errors would arise in ordering and purchasing tickets in advance, and that great vexation, inconvenience, and loss would come to the general public from the concurrent production of two such plays under the same name. ${ }^{44}$

Two other cases reveal more favorably the position of the plaintiff in the California courts than in New York. In a California case, ${ }^{45}$ the author of the poem title "The Ballad of Yukon Jake," was granted an injunction restraining the exhibition of a motion picture titled. "Yukon Jake." The court pointed out: ${ }^{46}$

The public, familiar with the poem aud its story, would be inpelled to view any picture exhibited under the title "Yukon Jake" in the behef that it

\footnotetext{
11 Frohman v. Miller, 8 Misc. 379, 29 N.Y. Supp. 1109 (Sup. Ct. 1894).

42 Id. at 381,29 N.Y. Supp. at 1111.

4368 Misc. 461, 123 N.Y. Supp. 1090 (Sup. Ct. 1910).

44 Id. at 464, 123 N.Y. Supp. at 1092.

45 Paramore v. Mack Sennett, 9 F.2d 66 (S.D. Cal. 1925).

46 Id. at 68 .
} 
would portray the characters and incidents in the plaintiff's poem; that upon the exhibiting of the defendant's picture, occurring before plaintiff had sold his scenario, there would no longer be the same demand for a second picture under a title containing the words "Yukon Jake," and the marketability of plaintiff's scenario would thus be proportionately destroyed.

A New York court, ${ }^{4 \pi}$ however, said: "No danger exists that the patrons of the moving picture will be misled into the belief that they are to witness a performance of the spoken drama." The New York court ignored the fact that the author of the drama would probably be charged with the authorship of the motion picture.

Trade-marks and trade names are not transferable in gross: A naked trade-mark is a nullity. Although a title is no more independent than a trade-mark, there is a lively trade in titles alone, divorced from text or script, especially in the motion picture industry. There titles are of such great value that the Motion Picture Producers and Distributors of America maintain an elaborate system for their registration, and companies often buy a title irrespective of the literary property with which it is connected in order to obtain use of the title and nothing else and not infrequently pay $\$ 10,000$ to $\$ 20,000$ for a title.

How is that possible? You cannot buy a naked trade-mark or trade name. Is it different with titles: Is it legally correct to say, as one party argued in a brief: . . . "busmess practice has so developed and the law must recognize that certain names and titles have a marketable value and are the subject of commercial traffic." 48 In principle, the answer is "No." But the economic effect of a naked transfer is reached by the following argument:

Under the Califorma statutes and under the common law the owner of a title has the exclusive right to it. This exclusive right includes: its use as the title of a book, a silent or talking motion picture, a radio broadcast, a dramatic production, or a television program. And the owner of the rights to these separate uses of his title can grant the exclusive right to use it for one or more of those purposes. That makes pretty good sense.

And the law is not different when the content of the book, that is, its literary material, has lost its value completely and the only remaining value is $\mathrm{m}$ the use of the title. So it was with the book "Queen of the Flat Tops" 49 which described the activities of an aircraft carrier in combat. The court, after finding that the book itself had lost its popularity as such, remarked: ${ }^{50}$

47 Underhill v. Schenck, 238 N.Y. 7, 143 N.E. 773 (1924).

4 J Johnston v. Twentieth Century-Fox Film Co., 82 Cal. App.2d 796, 187 P.2d 474 (1947).

49 Ibid.

50 Id. at 817,187 P.2d at 487 . 
The title . . . was produced by shrewd calculation. It is an original combination, a catchy phrase. It had sales appeal. Much time, energy, and money were spent in popularizing it. A thing of such great value should not only be protected but should be subject to transfer for use.

And it was indeed sold for $\$ 20,000$.

To this point, we have discussed cases in which the courts followed the International News Service case by charging those "who reap where they have not sown" with unfair coinpetition. We have also seen that there are inore, or at any rate too many, cases where the courts refuse to do so. Perhaps they share Brandeis' view in his famous dissent to the International News Service case in the belief that the mere fact that a famous product of the mind has cost its producer money and labor does not convert the idea into a property right. For "the general rule of law is, that the noblest of human productions - knowledge, truths ascertained, conceptions, and ideas - become, after voluntary communication to others, free as the air to common use." ${ }^{\text {51 }}$ Furthermore, as Mr. Justice Brandeis said: ${ }^{52}$

To appropriate and use for profit, knowledge and ideas produced by other men, without making compensation or even acknowledgement, may be inconsistent with a finer sense of propriety; but, with the exceptions [under copyright and patent statutes or in cases of special relationship "where the suit is based upon breach of contract or of trust or upon unfair competition"] the law has heretofore sanctioned the practice.

We miglit be content with this statement, for even Mr. Justice Brandeis expressly excepts unfair competition. But the concept of unfair competition itself is not yet beyond dispute and Mr. Justice Brandeis excluded the Associated Press case from his exceptions even though there was admittedly competition. We must therefore probe the social and legal foundations of our economic life to justify our premise, that, at least in the fields of competitive struggle, a reaping of another's harvest is illegal. These policy questions take on more clarity as we examine the conditions under which the law expressly sanctions that which would otherwise be a case of unjust enricliment.

In terms of evolution, it cannot be denied that all members of civilized society "reap where they have not sown." Unlike Pallas' Athene, new patterns of thouglit and understanding do not spring into being fully conceived. As a rule, it is a fundamental law of human progress and, of course, a triviality that the experience and wisdom of each generation is the heritage of the next, and from this cultural milieu, creative achievement can never be divorced. Indeed, progress, in our terms, is measured by the improvements of or refinements on existing values. In this respect, there is indeed validity

51248 U.S. 215, 250 (1918).

52 Id. at $25 \%$. 
to the maxim "there's nothing new under the sun." And so it must be seriously doubted whether any law could or should prevent even conscious appropriation of knowledge, let alone the impossible problem of unconscious imitation.

Men consciously borrow from each other; as pupils, they study the systems, styles, or schools of the great masters; as engineers, they seek to improve upon the inventions of their predecessors; as practitioners, they must, of necessity, use and apply the fundamental rules of the scientist. Generally speaking, ideas and their realizations are the mentors of mankind. But only the realization has any claim to legal protection, and even that is subject to strict limitations. As a rule: where legal protection is granted to property, public policy determines its peculiar tenor; and administrative difficulty usually prompts denial of protection.

But no one in business doubts that abstract ideas should be protected and that public policy cries out for their protection; but "where are the indicia or distinguishing marks of ideas? What distinguishing marks can a man fix upon a set of intellectual ideas, so as to call himself the proprietor of them? They have no earmarks upon them ...." These queries, posed by Judge Yates in his dissenting opimion in Millar v. Taylor, ${ }^{53}$ are still unanswered, and therefore, this is still the law today: The doctrine that an author has a right of property in his ideas and is entitled to demand for them the same perpetual protection which the law accords to the proprietor of personal property generally, finds no recognition either in the common law or in the statutes of any civilized country.

The admimistrative difficulties that are necessarily involved in any attempt to protect an idea are admittedly insurmountable; the idea itself is too abstract without "reduction to practice";

... the mental conception must have been susceptible of embodiment and must have been, in fact, embodied in some mechanical device, or some process of art. The abstract must have been resolved into the concrete. The protection must be for a thing -not for an idea merely..$^{54}$

The law doesn't have to be so confused. The approach shouldn't be so technical and the so-called administrative difficulties have been unduly exaggerated. One can readily appreciate why the businessman is hesitant to encourage the revelation to hun of an outsider's idea. The risk of being held responsible in a nuisance suit is too great. ${ }^{55}$ I believe, lowever, that we have been making the problem more weighty than it really is. The use a defendant makes of an idea or title is a readily provable matter, and it should be

534 Burrows 2303, 2366, 98 Eng. R. 201, 235 (1769).

54 Detmold v. Reeves, 7 Fed. Cas. No. 3,831 (C.C.S.D. Pa. 1851).

65 Cf. Solinger, Idea-Piracy Claims-or Advertiser, Bewarel, 1953 Copyrighr Problens ANAIYZZE, CCH 131ff (1953). 
sufficient that a description of the idea conveys to the public a full understanding of its individuality. A realistic appraisal can be based upon the objective facts that the idea, though not absolutely new, has not been used before and was unknown to the recipient. A palatable formula can be found and our courts can cope with it.

Principles are, of course, necessary, but they must be our guides and not our masters. The flexibility of the common law is its chief advantage and we should exploit it.

Though perhaps expected to offer the all-important solution, I am hard put to do so, but would like to offer my thoughts for whatever they may be worth: The idea should be protected as a property right, without reference to any so-called concrete manifestation, if and only if it is identifiable and practicable. If such an idea is offered and the recipient has not in fact used it before but does use it after, we can establish the presumption that it was not known to him and was valuable to him; hence, the originator should be fairly rewarded. If the recipient can demonstrate that he had prior knowledge of the idea, the presumption can be rebutted. As a guiding principle, unjust enrichment should be avoided. When counselling the idea man, make sure his idea is expressed in a readily identifiable form. When representing the recipient, make certain that he is ready to pay for his use of a newlyrevealed idea or caution him not to use it unless he can establish prior knowledge. 